\title{
Seasonal Variation in Physicochemical Properties of Groundwater, a Case Study of Kamiti-Marengeta Subcatchment Kiambu, Kenya
}

\author{
Miriam Judith Adongoㄹ, Mary Kalibala Makokha', Joy Apiyo Obando', Jacob Odhiambo Ochieng² \\ ${ }^{1}$ Department of Geography, Kenyatta University, Nairobi, Kenya \\ ${ }^{2}$ Department of Environmental Science, Kenyatta University, Nairobi, Kenya \\ Email: adongomiriam@gmail.com,makokha.mary@ku.ac.ke,obando.joy@ku.ac.ke, ochyjacks@gmail.com
}

How to cite this paper: Adongo, M.J., Makokha, M.K., Obando, J.A. and Ochieng, J.O. (2022) Seasonal Variation in Physicochemical Properties of Groundwater, a Case Study of Kamiti-Marengeta Subcatchment Kiambu, Kenya. Journal of Water Resource and Protection, 14, 72-85.

https://doi.org/10.4236/jwarp.2022.142005

Received: January 10, 2022

Accepted: February 12, 2022

Published: February 15, 2022

Copyright () 2022 by author(s) and Scientific Research Publishing Inc. This work is licensed under the Creative Commons Attribution International License (CC BY 4.0).

http://creativecommons.org/licenses/by/4.0/

(c) (i) Open Access

\begin{abstract}
The seasonal variation and quality status of groundwater systems of KamitiMarengeta sub-catchment were evaluated through analysis of boreholes and 17 shallow wells water samples in May 2016 and September 2017. Consequently, the results were compared against the Kenya Bureau of Standards (KEBS) and World Health Organization (WHO) guidelines for drinking water purposes, and its suitability for drinking was established. The results showed that turbidity, calcium, potassium, iron, and fluoride levels in some of the boreholes and $\mathrm{pH}$, calcium, sodium, and iron levels in some shallow wells exceeded the KEBS and WHO standards for drinking water quality. Turbidity, dissolved oxygen, and total hardness significantly varied across the regions of the study, and one-way ANOVA $(\mathrm{P}<0.05)$ indicated a significant difference in the mean concentration of electrical conductivity, turbidity, total hardness, calcium, and iron in boreholes and in all parameters in shallow wells except for magnesium during the two seasons. The findings of this study provide baseline information on the quality of the groundwater systems of the area. It also contributes to knowledge on seasonal variation of groundwater quality of volcanic aquifers like the Nairobi Aquifer System (NAS) which is important for water quality monitoring.
\end{abstract}

\section{Keywords}

Groundwater, Water Quality, Seasonal Variation

\section{Introduction}

Freshwater is one of the valuable natural resources whose both quality and 
quantity are indispensable for sustainable development [1]. The concept of water quality has become so important because it affects the use of water resources as well as human and ecological health. The human population is globally increasing. According to Knox \& Marston, rapid population growth has created a significant amount of stress on local, regional, and global environments [2]. Today the world faces various challenges in meeting both the ecological and human water demands. The increase in human population, rapid urbanization, rising living standards across the world, poor waste management, and environmental degradation put freshwater resources under increasing stress.

In Kenya, management and monitoring responsibility of all water resources is done by the state; typically, the use of water depends on approval and a water permit which clearly states the water use, the amount approved for abstraction, and how long the permit will be valid [3]. Despite the conditions of the law, groundwater management in Kenya is still influenced by people's perception of groundwater as a private resource that is owned by the landowner. Groundwater is therefore treated and perceived as a resource with great benefits to everyone with most of the users exploiting it and ignoring the likely consequences of unregulated use. Knowledge on seasonal variation of groundwater quality of volcanic aquifers like the Nairobi Aquifer System (NAS) is rare, yet this is important for water quality monitoring. Groundwater quality issues such as high fluoride and salinity levels in the groundwater of the NAS are major concerns for human health and general water resources development but it remains overexploited. Increased demand for water from rapid population increase in KamitiMarengeta sub-catchment has resulted in an upsurge of groundwater abstraction for water supply.

According to the National Population Census 2019, the population of Kiambu County, in central Kenya with a landmass of $2538.6 \mathrm{Km}^{2}$ has significantly grown from 914,412 in 1989 [4] to 2,417,735 in 2019 [5]. This continuous increase in population in Kahawa Wendani, Kahawa Sukari, Kenyatta University, Eastern Bypass, Membley, and Kiwanja which are the residential areas of Kamiti-Marengeta sub-catchment in Kiambu County has subsequently increased the demand for both housing and water supply services. Ruiru-Juja Water and Sewerage Company (RUJUWASCO), the water service provider, has failed to keep pace with the increasing demand since it is only capable of meeting $14 \%$ of the water demand [6]. The effect of this is that most of the housing developers have resorted to the exploitation of groundwater.

Even though Water Resources Management Authority is obliged to monitor and regulate the use of groundwater resources, the groundwater quality monitoring activity is limited by inadequate infrastructural development funds needed to put up dedicated groundwater monitoring networks and facilitate the collection and analysis of groundwater data. There are only 40 groundwater monitoring networks in the entire Athi Catchment Area (ACA) which is inclusive of Nairobi, Kiambu, Mombasa, Loitoktok, and Machakos sub-regions [7]. The serious need for water by households, weak monitoring, and management frame- 
works for groundwater, as well as the high cost of groundwater treatment, has seen most of the borehole water pumped directly to the house taps or storage tanks without any form of treatment posing health risks to the users.

This study assessed the seasonal variation and quality status of groundwater systems of Kamiti-Marengeta and sub-catchment and consequently establishes its suitability for domestic use. The outcome of this study provides baseline information on the quality of the groundwater systems of the area; knowledge on the inter-seasonal variation of groundwater quality on a volcanic aquifer whose main aquifer unit is unconfined in the recharge zone but progressively gets confined and thins towards the end at the confined and thin area; knowledge on how water quality varies within an aquifer and factors determining these; and information that can help Water Resources Authority and the County Government in coming up with strategies to address groundwater quality problems and mitigation measures to ensure the provision of safe water to residents.

\section{Location and Extent}

Geographically the study area is bounded by the following coordinates $36^{\circ} 95^{\prime} \mathrm{E}$ and $1^{\circ} 16^{\prime} \mathrm{S}$ and $36^{\circ} 97^{\prime} \mathrm{E}$ and $1^{\circ} 21^{\prime}$ as shown in Figure 1 below. The study area is an outskirt residential area comprising of six distinct zones; Kahawa Wendani, Kahawa Sukari, Kenyatta University, Eastern Bypass, Membley, and Kiwanja that goes across Nairobi and Kiambu County border along Thika Road. The area

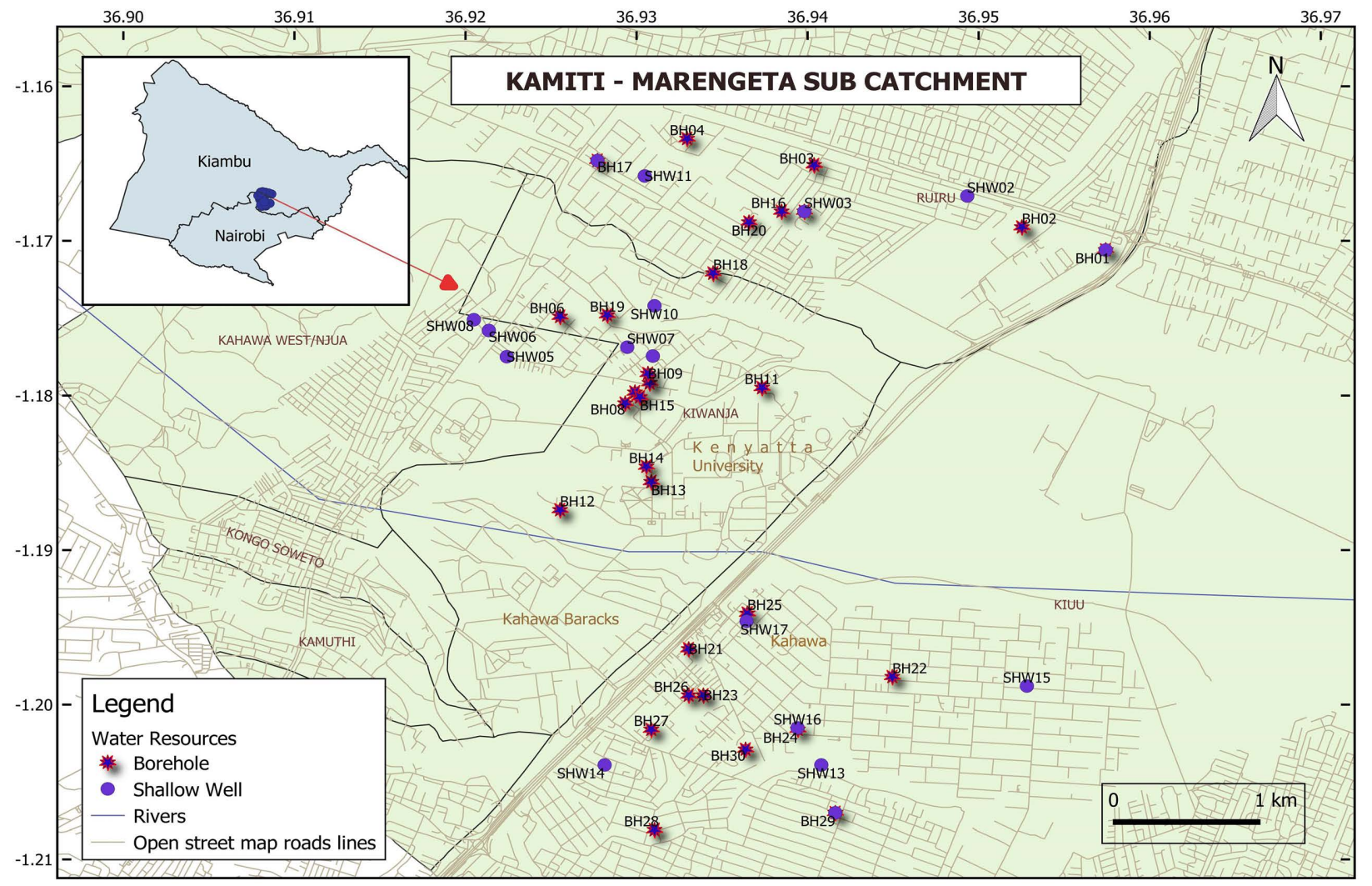

Figure 1. Map of Kamiti-Marengeta sub-catchment showing the distribution of sampled boreholes. 
is well-drained by the Kamiti River and its tributaries-Marengeta and Kiu River. The climate of Kamiti-Marengeta sub-catchment is generally warm with temperatures ranging between $13^{\circ} \mathrm{C}$ and $25^{\circ} \mathrm{C}$. Vegetation cover is mainly comprised of long and short grass maintained by local precipitation of 900 millimeters per year. The surface geology is composed of reddish to brownish soils and marram derived from the in-situ weathering of volcanic rocks. These soils are underlain by the Athi series both upper and lower series, mainly comprising sediments and tuffs. The probable aquifers in this area are struck within the Athi Series. Replenishing of these aquifers is through vertical infiltration and lateral percolation of surface water. The aquifer's transmissivity and hydraulic conductivity values of the aquifer vary from 0.1 to $160 \mathrm{~m}^{2} / \mathrm{d}$ and 0.01 to $1.3 \mathrm{~m} / \mathrm{d}$ respectively with storage coefficient values of between $1.2 \times 10^{-4}$ to $4.2 \times 10^{-1}$ [8].

\section{Research Methodology}

A total of 47 groundwater samples, 30 from boreholes and 17 from shallow wells spread across the study area, were sampled in May 2016 for the wet season and September 2017 for the dry season to cover the general difference in hydrologic and chemical conditions that vary due to the dynamic groundwater environment. Universally accepted standards procedure described by the American Public Health Association (APHA) [9] were used during sample collection. At the time of sampling, the sampling bottles had been sterilized with $10 \%$ nitric acid and cleaned with deionized water. These were thoroughly rinsed with the water being sampled before the sample was collected. Samples from the wells with a pumping mechanism were taken after the water had been pumped out for about 5 minutes to prevent the collection of non-representative samples of polluted or stagnant water in the pipes [9]. Samples from shallow wells without a pumping mechanism were collected directly from the wells using a sterilized bottle fitted with a weight at the base with a lot of care to avoid contamination of the sample by any surface scum. During sampling, an ample air space of at least $2.5 \mathrm{~cm}$ was left to facilitate mixing by shaking before laboratory analysis was done [9]. Geographically referenced coordinates of sampling sites were recorded with the help of a hand-held Global Positioning System (GPS) receiver. Samples were then transferred to the Kenyatta University Laboratories for analysis. In cases where arrival to the laboratories was late, the samples were refrigerated overnight for processing the following day.

Temperature, $\mathrm{pH}$, dissolved oxygen, total dissolved solids, and electrical conductivity of samples were determined in-situ at the sample collection site by the use of the AQUALYTIC ${ }^{\circledR}$ AL15 Multimeter instrument, which has combined features of various water quality portable meters [10]. The turbidity of the water samples was determined through the nephelometric method using an AQUALYTIC ${ }^{\circledR}$ AL450T-IR turbidity meter with an infrared light source. Fluoride concentration was determined through the SPADNS colorimetric method and iron through the colorimetric method after the addition of one Vario Ferro F10 Powder Pack into 
the sample vial. Chloride concentration level was determined by the use of a mercuric nitrate $\mathrm{Hg}\left(\mathrm{NO}_{3}\right)_{2}$ titration [10]. Hardness concentration was done through ethylenediaminetetraacetic acid (EDTA) titration. Nitrate and Sulphate concentration in the samples were determined through the ultraviolet spectrophotometric screening method and concentrations of calcium, magnesium, and sodium were determined through a flame atomic absorption spectrophotometer [9].

The data obtained from onsite and laboratory analysis were analyzed using Microsoft Excel and Statistical Package for Social Sciences (SPSS). One-way analysis of variance (ANOVA) [11] was performed to determine differences in concentration of the tested parameters in boreholes across the six zones of the sub-catchment considering the fact the main water supply unit of the aquifer thins spatially. After running ANOVA, Tukey's Honest Significant Difference (HSD) test was performed to compare all probable pairs of means to determine which specific groups' means were different. The student's t-test [12] performed at a $95 \%$ confidence interval was used to determine significant differences between seasons in the mean concentration of the tested parameters in boreholes and shallow wells.

\section{Results and Analysis}

\subsection{Physical and Chemical Characteristics of Groundwater Systems}

All the $\mathrm{pH}$ values of the 30 sampled boreholes were found to be within the WHO and KEBS standards of between 6.5 and 8.5 during the wet and dry period. The $\mathrm{pH}$ values for the 17 sampled shallow wells were found to be within the WHO and KEBS standards during the wet period however during the dry period three shallow wells, SHW7 in Kiwanja and SHW 9 and SHW 10 in Membley, recorded $\mathrm{pH}$ values lower than the World Health Organization (WHO) and Kenya Bureau of Standards (KEBS) guidelines as shown in Figure 2. $\mathrm{pH}$ as a water quality parameter is important as it shows whether the water is acidic or alkaline in nature. The lower the groundwater $\mathrm{pH}$ value is the more acidic the water is. On average during both the dry and wet seasons the water from the sampled boreholes was

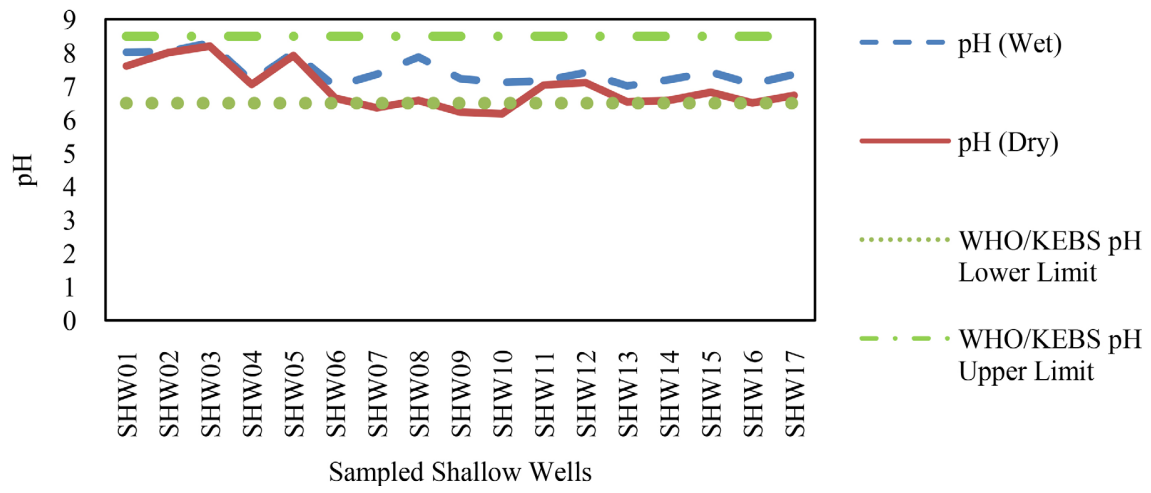

Figure 2. Graph showing $\mathrm{pH}$ measure in shallow wells. 
alkaline. Shallow wells were slightly acidic during the dry season. This finding is like the one reported by Yankey [13] who found natural waters to be slightly acidic with values ranging from (5.0 - 7.5). Conversely, the acidity may have also been caused by the presence of organic acids and carbon dioxide within the soil zone or from the biogeochemical processes taking place during decay and leaching of plant materials from the use of poultry waste in gardening and managing waste through composting [13].

Turbidity values above the WHO \& KEBS permissible limits of 5UNT was recorded in 5 boreholes, BH17, BH19, BH16, and BH 20 in Membley and BH02 in Bypass, during both dry and wet seasons and 4 shallow wells, SHW 10, SHW11, SHW12 in Membley and SHW14 in Kahawa Wendani during the wet season as shown in Figure 3 and Figure 4. High turbidity in water results from a suspension of clay, silt, organic matter, and microscopic organisms. Turbidity of water suggests the extent to which the water is polluted. Turbidity of water is of significance because the colloidal particles provide hideouts for pathogens [14]. Potassium concentration above the KEBS permissible limit of $50 \mathrm{mg} / \mathrm{l}$ was recorded in 16 boreholes during the two seasons. This high concentration was also recorded in 10 shallow wells during the dry season and 14 shallow wells during the wet season as shown in Figure 5 and Figure 6. The increase in concentrations of potassium in shallow wells during the wet season can be attributed to an

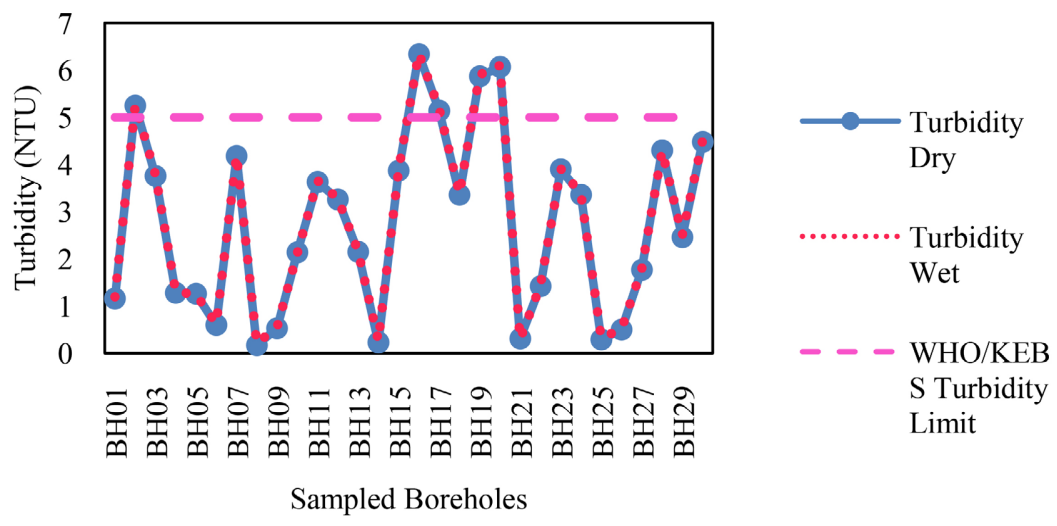

Figure 3. Graph showing turbidity of borehole water samples.

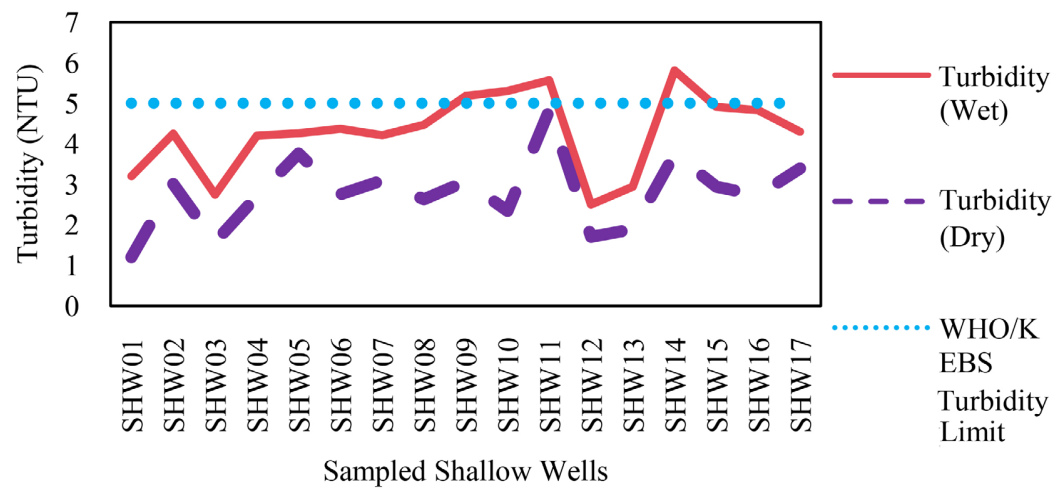

Figure 4. Graph showing turbidity measure in shallow wells. 


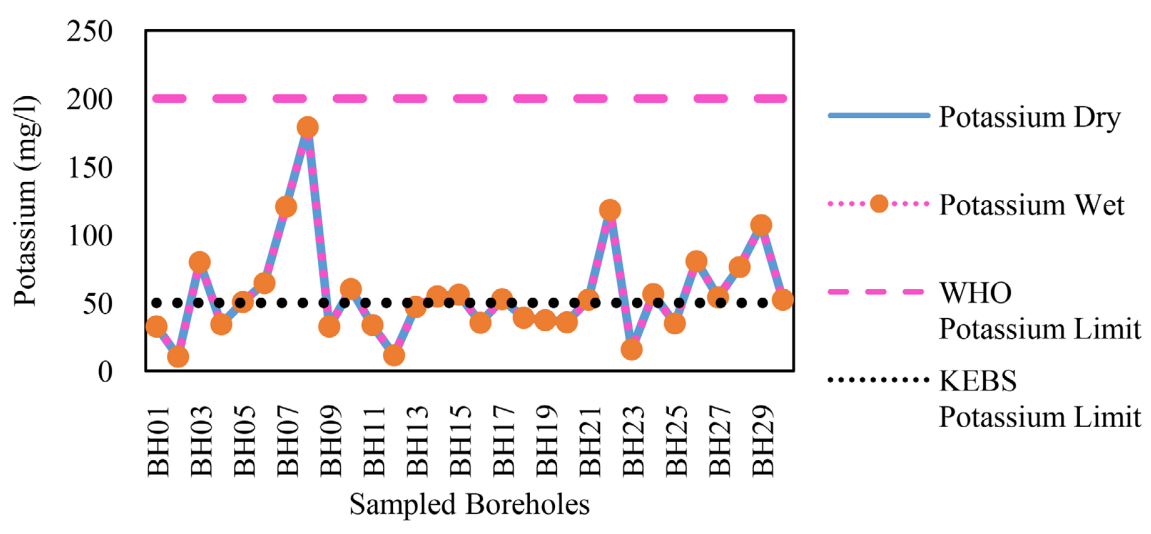

Figure 5. Graph showing the concentration of potassium in boreholes.

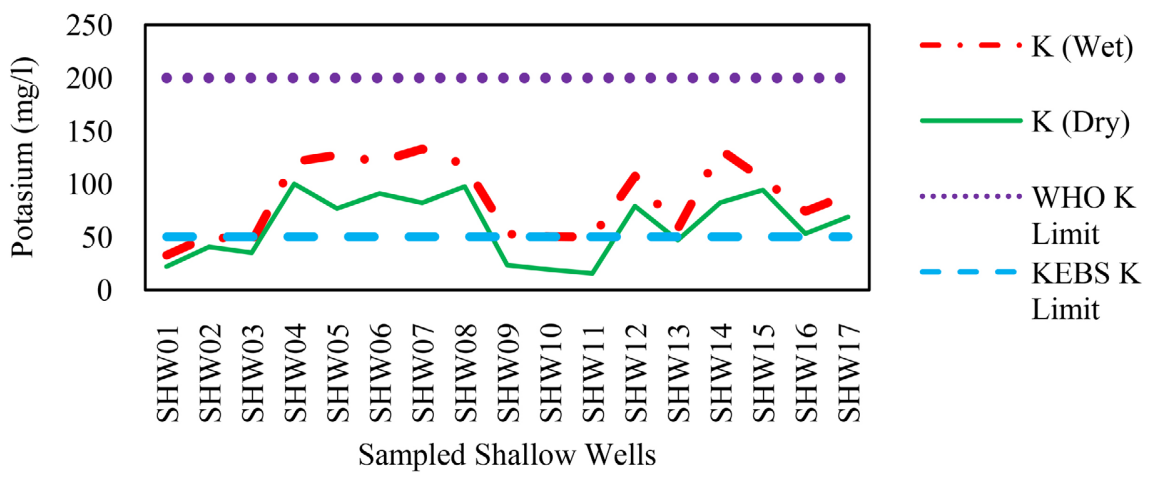

Figure 6. Graph showing the concentration of potassium in shallow wells.

increase in seepage of agrochemicals and domestic sewage into the wells considering how close some of these wells are to the farms, septic tanks, and open sewers.

Iron concentration above the KEBS standards of $0.3 \mathrm{mg} / \mathrm{l}$ was recorded in six boreholes. BH 24 in Kahawa Sukari, BH 12 and BH 15 in Kenyatta University, and $\mathrm{BH} 5$ and $\mathrm{BH} 4$ in Bypass exhibited high iron concentration above the KEBS standards of $0.3 \mathrm{mg} / \mathrm{l}$ whereas $\mathrm{BH} 23$ in Kahawa Sukari exhibited high iron concentration above both WHO and KEBS standards of $0.3 \mathrm{mg} / \mathrm{l}$ and $0.5 \mathrm{mg} / \mathrm{l} \mathrm{re}-$ spectively during the dry and wet season. Three sampled shallow wells, SHW03 and SHW02 in bypass and SHW08 in Kiwanja, exhibited high iron concentration above the KEBS standards of $0.3 \mathrm{mg} / \mathrm{l}$ during the wet season as shown in Figure 7 and Figure 8. The concentration of calcium in all sampled boreholes and shallow wells was below the WHO standards of $100 \mathrm{mg} / \mathrm{l}$ and KEBS standards of $150 \mathrm{mg} / \mathrm{l}$ except for $\mathrm{BH} 07$ in Kiwanja borehole during both dry and wet seasons and SHW04 in Kiwanja shallow well during the wet season as shown in Figure 9 and Figure 10. The increase in mean concentrations of calcium in shallow wells during the wet season can be ascribed to the storm run-off which may increase its concentration. Calcium is a significant element of groundwater hardness and plays a significant role in stabilizing groundwater $\mathrm{pH}$ due to its buffering attributes. Calcium also gives water a better taste. Even though the sources of calcium in groundwater systems are majorly crystalline limestone 


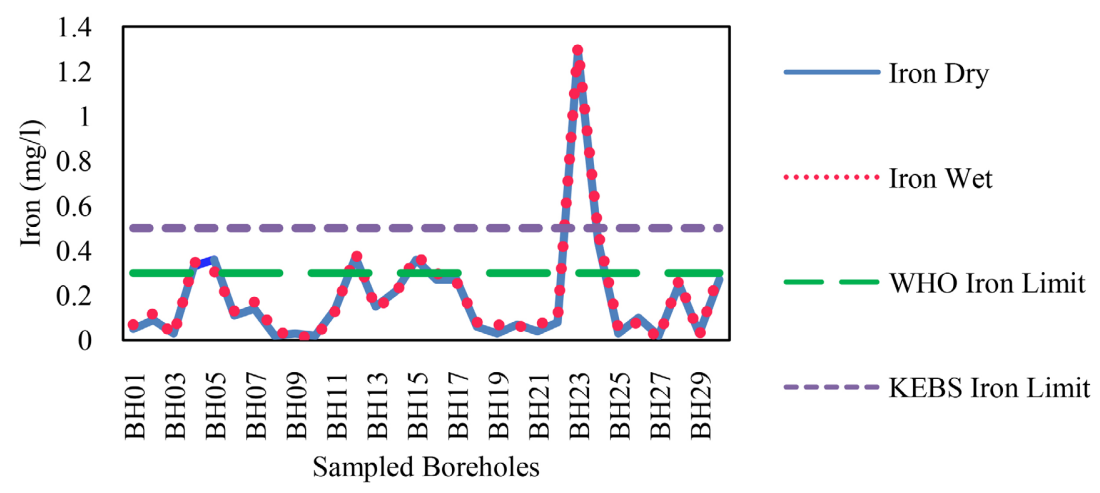

Figure 7. Graph showing the concentration of Iron in borehole water.

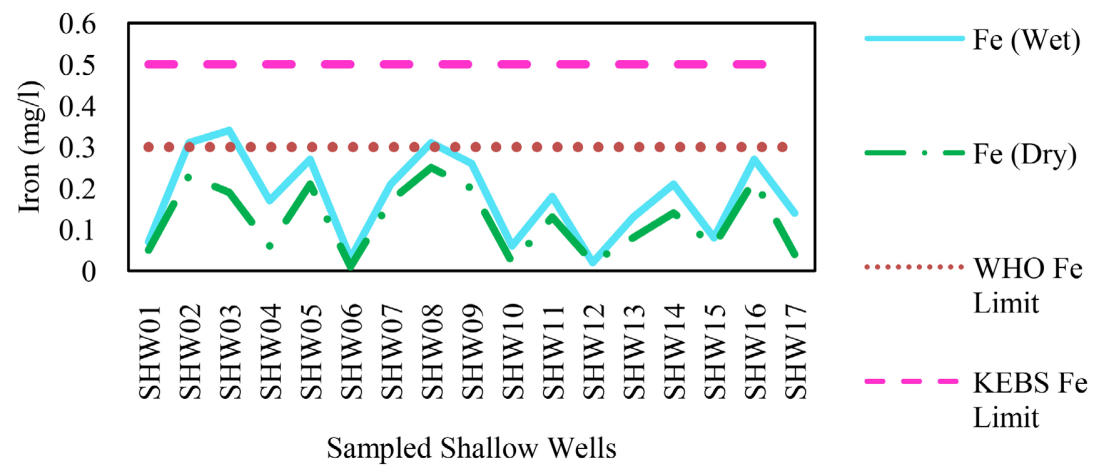

Figure 8. Graph showing the concentration of iron in shallow wells.

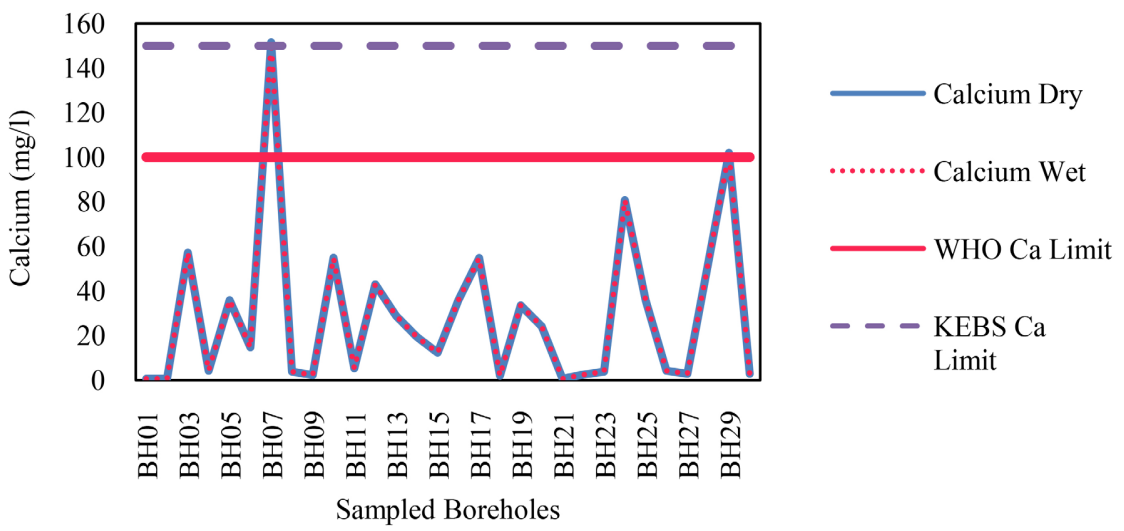

Figure 9. Graph showing the concentration of calcium in boreholes.

linked with khondalitic rocks [15], sustained agricultural activities such as vegetable kitchen gardening, and poultry keeping near some shallow wells in the study area could also increase calcium concentration.

The concentration of fluoride in all sampled boreholes and shallow wells was below the WHO and KEBS set standards of $1.5 \mathrm{mg} / \mathrm{l}$ except for 2 boreholes, BH20 in Membley and BH08 in Kiwanja during both dry and wet seasons as illustrated in Figure 11. Sodium in all sampled boreholes and shallow wells was below WHO and KEBS permissible limits of $200 \mathrm{mg} / \mathrm{l}$ except for SHW02 in Bypass during the wet season as shown in Figure 12. Sodium is a mobile chemical 


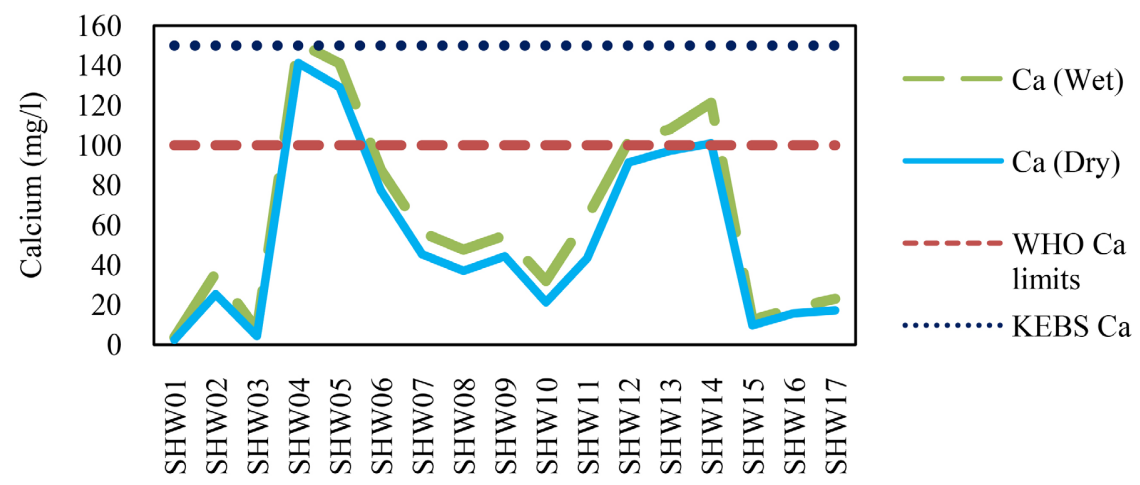

Sampled Shallow Wells

Figure 10. Graph showing the concentration of calcium in shallow wells.

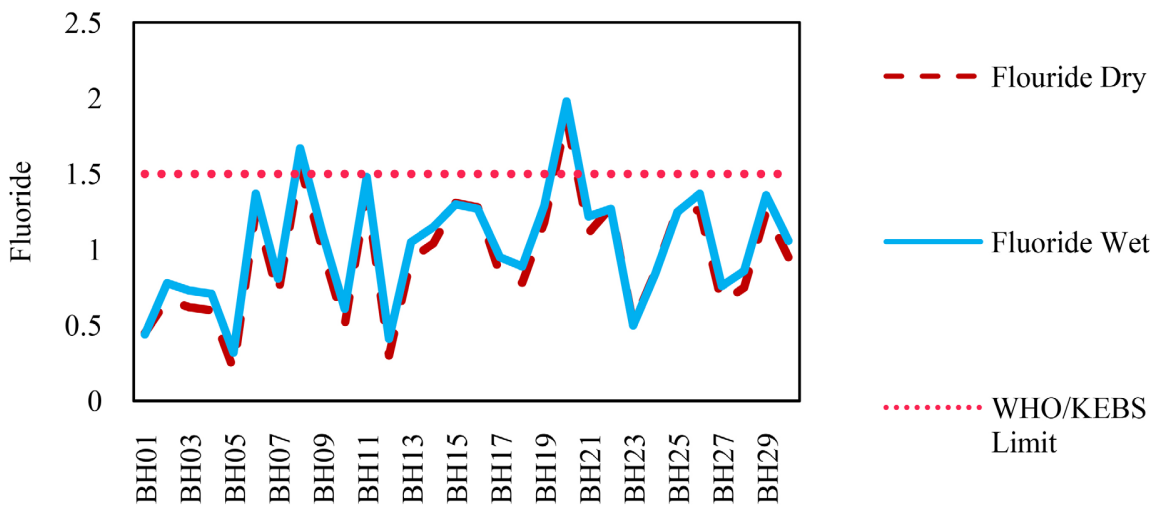

Sampled Boreholes

Figure 11. Graph showing the concentration of fluoride in boreholes.

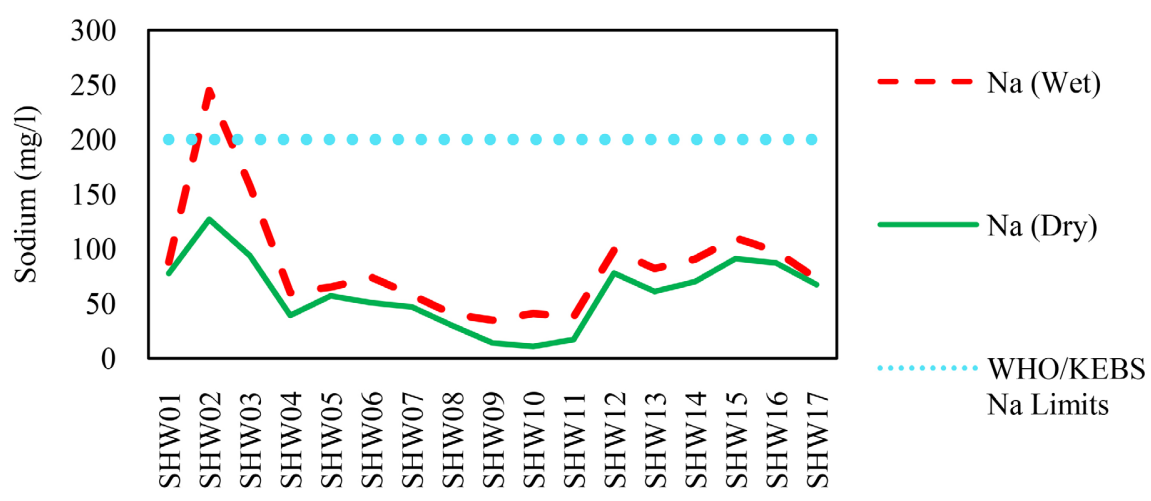

Sampled Shallow Wells

Figure 12. Graph showing the concentration of sodium in shallow wells.

commonly found in rocks and soils and is often used as an indicator of anthropogenic impacts on groundwater [16]. Due to its solubility, sodium is always present in groundwater. Sodium is a very important constituent but only in low concentrations of less than $200 \mathrm{mg} / \mathrm{l}$. Sodium is responsible for the taste of water; hence, in high values, it creates an unpleasant salty taste in drinking water mak- 
ing it unsuitable for people with hypertension and cognitive heart failure due to salt retention.

\subsection{Variation in Concentration of the Tested Parameters in Boreholes across the Six Zones of the Sub-Catchment}

One-way analysis of variance (ANOVA) $(\mathrm{P}>0.05)$ indicated no statistically significant difference in concentration levels in 14 tested parameters: Temperature, $\mathrm{pH}, \mathrm{EC}$, Total dissolved solids (TDS), total alkalinity, magnesium, calcium, sodium, potassium, iron, fluoride, chloride, nitrate, and sulphate in boreholes in different zones of the study area during both wet and dry season as shown in summary Table 1 . However, there was a statistically significant difference $(\mathrm{P}<$ 0.05) in concentration levels of Turbidity, Dissolved Oxygen, and Total Hardness in boreholes in different zones of the study area during both wet and dry season with $\mathrm{P}=0.02, \mathrm{P}=0.00$, and $\mathrm{P}=0.03$ respectively. Mean separation procedure with Turkey's test at $95 \%$ confidence interval revealed that the statistical difference in concentration was placed between.

Kiwanja and Kenyatta University at $\mathrm{P}=0.13$ and Kenyatta University and Kahawa Wendani at $\mathrm{P}=0.00$ for dissolved oxygen (DO); bypass and Membley at $\mathrm{P}=0.012$ and Bypass and Kahawa Wendani at $\mathrm{P}=0.041$ for Total at Hardness;

Table 1. Variations in the concentration of the tested parameters across the regions of the study area during dry and wet seasons.

\begin{tabular}{|c|c|c|c|c|c|}
\hline \multirow{2}{*}{ Parameter } & \multirow{2}{*}{ Df } & \multicolumn{2}{|c|}{ Dry Season } & \multicolumn{2}{|c|}{ Wet Season } \\
\hline & & F & P-value & F & P-value \\
\hline Temperature $\left({ }^{\circ} \mathrm{C}\right)$ & 29 & 1.97 & 0.12 & 1.79 & 0.15 \\
\hline $\mathrm{pH}$ & 29 & 1.15 & 0.36 & 1.4 & 0.26 \\
\hline Electrical Conductivity $(\mu \mathrm{S} / \mathrm{cm})$ & 29 & 1.49 & 0.23 & 1.48 & 0.23 \\
\hline Turbidity (NTU) & 29 & 3.50 & $0.02^{* *}$ & 3.53 & $0.02^{\star *}$ \\
\hline Total Dissolved solids (mg/l) & 29 & 0.38 & 0.86 & 0.38 & 0.86 \\
\hline Dissolved Oxygen (mg/l) & 29 & 5.15 & $0.00^{* *}$ & 5.11 & $0.00^{\star *}$ \\
\hline Total Hardness (mg/l) & 29 & 3.13 & $0.03^{\star *}$ & 3.13 & $0.03^{* *}$ \\
\hline Total Alkalinity (mg/l) & 29 & 1.18 & 0.35 & 1.17 & 0.35 \\
\hline Magnesium (mg/l) & 29 & 0.56 & 0.73 & 0.56 & 0.73 \\
\hline Calcium (mg/l) & 29 & 0.32 & 0.90 & 0.32 & 0.90 \\
\hline Sodium (mg/l) & 29 & 1.09 & 0.39 & 1.22 & 0.33 \\
\hline Potassium (mg/l) & 29 & 2.11 & 0.10 & 2.11 & 0.10 \\
\hline Iron $(\mathrm{mg} / \mathrm{l})$ & 29 & 1.00 & 0.44 & 1.08 & 0.40 \\
\hline Fluoride (mg/l) & 29 & 2.01 & 0.11 & 2.04 & 0.11 \\
\hline Chloride (mg/l) & 29 & 1.95 & 0.12 & 1.95 & 0.12 \\
\hline Nitrate (mg/l) & 29 & 0.84 & 0.53 & 0.87 & 0.52 \\
\hline Sulphate (mg/l) & 29 & 0.33 & 0.89 & 0.33 & 0.89 \\
\hline
\end{tabular}

**highlights $\mathrm{P}$ values that are less than 0.05 . 
and Kiwanja and Membley at $\mathrm{P}=0.011$ and between Membley and Kahawa Sukari at $\mathrm{P}=0.02$ for Turbidity.

The turkey results confirmed that despite the water being from the same aquifer, the concentration of these three parameters was not uniform across the study area. This could be attributed to different levels of exposure of the groundwater to pollution from soil and sewage intrusion, renewed suspension of silt, and sediments through fractures within the aquifer. The variation in concentration of these parameters across the mentioned regions is significant in this study as it can help determine the source of pollution to the groundwater.

\subsection{Seasonal Variation in Physicochemical Water Quality Parameters of Sampled Boreholes and Shallow Wells during the Dry and Wet Season}

The student's t-test analysis performed for the 30 samples at $95 \%$ confidence interval indicated that there was no statistically significant difference $(P>0.05)$ between dry and wet season for temperature, $\mathrm{pH}$, TDS, DO, Total Hardness, Magnesium, Sodium, Potassium, Fluoride, Chloride, Nitrate and Sulphate in sampled boreholes except for EC, Turbidity, Total Hardness, Calcium, and iron. A statistically significant difference $(P<0.05)$ between dry and wet season was recorded in 16 tested parameters $(\mathrm{P}=0.000)$ except for Magnesium $(\mathrm{P}=0.052)$ in shallow wells as shown in Table 2 below.

Table 2. Comparison of physical and chemical parameters of groundwater quality from boreholes during the wet and dry.

\begin{tabular}{ccccccc}
\hline \multirow{2}{*}{ Parameter } & \multicolumn{3}{c}{ Boreholes } & \multicolumn{3}{c}{ Shallow Wells } \\
\cline { 2 - 7 } & $\mathrm{T}$ & $\mathrm{Df}$ & $\mathrm{P}$-Value & $\mathrm{T}$ & $\mathrm{df}$ & P-Value \\
\hline Temperature $\left({ }^{\circ} \mathrm{C}\right)$ & -1.36 & 29 & 0.18 & -8.491 & 16 & 0.000 \\
Electrical Conductivity $(\mu \mathrm{S} / \mathrm{cm})$ & -3.85 & 29 & $0.00^{* *}$ & 7.491 & 16 & 0.000 \\
Turbidity $(\mathrm{NTU})$ & -7.99 & 29 & $\mathbf{0 . 0 0 ^ { * * }}$ & 9.618 & 16 & 0.000 \\
Total Dissolved solids $(\mathrm{mg} / \mathrm{l})$ & 0.11 & 29 & 0.91 & 6.252 & 16 & 0.000 \\
Dissolved Oxygen $(\mathrm{mg} / \mathrm{l})$ & -0.49 & 29 & 0.63 & 6.942 & 16 & 0.000 \\
Total Hardness $(\mathrm{mg} / \mathrm{l})$ & -5.82 & 29 & $0.00^{* *}$ & 6.810 & 16 & 0.000 \\
Total Alkalinity $(\mathrm{mg} / \mathrm{l})$ & -1.44 & 29 & 0.16 & 3.847 & 16 & 0.001 \\
Magnesium $(\mathrm{mg} / \mathrm{l})$ & -1.21 & 29 & 0.24 & -2.101 & 16 & $0.052^{* *}$ \\
Calcium $(\mathrm{mg} / \mathrm{l})$ & -2.35 & 29 & $0.03^{* *}$ & 7.341 & 16 & 0.000 \\
Sodium $(\mathrm{mg} / \mathrm{l})$ & -1.30 & 29 & 0.20 & 3.896 & 16 & 0.001 \\
Potassium $(\mathrm{mg} / \mathrm{l})$ & -2.06 & 29 & 0.05 & 7.499 & 16 & 0.000 \\
Iron $(\mathrm{mg} / \mathrm{l})$ & -2.42 & 29 & $\mathbf{0 . 0 2 * *}$ & 6.395 & 16 & 0.000 \\
Fluoride $(\mathrm{mg} / \mathrm{l})$ & -8.70 & 29 & 1.41 & 12.222 & 16 & 0.000 \\
Chloride $(\mathrm{mg} / \mathrm{l})$ & -6.44 & 29 & 4.86 & 10.259 & 16 & 0.000 \\
Nitrate $(\mathrm{mg} / \mathrm{l})$ & -6.44 & 29 & 4.85 & 9.483 & 16 & 0.000 \\
Sulphate $(\mathrm{mg} / \mathrm{l})$ & -4.33 & 29 & 4.18 & 10.103 & 16 & 0.000 \\
\hline
\end{tabular}

${ }^{\star *}$ highlights $\mathrm{P}$ values that are less than or equal to 0.05 . 
Seasonal variation in the mentioned parameters in borehole samples may be due to multiple factors. The presence of a higher learning institution (Kenyatta University) within the region and improved transport infrastructure has seen the population of Kamiti-Marengeta significantly grow within a short period. Considering that this area suffers an inadequate supply of water from the water and sewerage companies and most people depend on borehole water, there is a possibility that a lot of pumping is done during the dry season to meet the demand. Dry season pumping of water from boreholes on a vertical hydraulic gradient influences the movement of water from the unsaturated zones through the aquifer to the supply boreholes [17]. The seasonal variation in the above-mentioned parameters could also be attributed to the different depths of the boreholes. The supply aquifer, Nairobi Aquifer, whose main aquifer unit is the Upper Athi Series largely found between 120 and $300 \mathrm{~m}$ below ground level and thins eastwards [18] hence most boreholes are not drilled to the same depth. The difference in depth of boreholes within Kamiti-Marengeta could also be a contributing factor to seasonal variation in the water quality.

Lastly, construction blasting and induced vibrations during the rapid development of road and housing infrastructure within the study area could have easily generated seismic disturbances causing micro-fractures [19]. Most of the tested parameters in shallow wells showed an increasing trend in concentration during the wet season except for Temperature. Water from shallow wells is sensitive to land uses and human activities such as farming, use of fertilizers, and septic systems. The water that soaks into the ground in areas under heavy human activities is pulled down by gravity to the water table. The contaminants dissolved in the water are carried along and might not be fully filtered by the soil hence compromising the quality of shallow wells as they mainly get their waters from the highest water table. $76 \%$ of sampled shallow wells (13 out of 17) within Kamiti-Marengeta sub-catchment lacked proper infrastructure, which include a good drainage channel, concrete cover, and well aprons that increased their vulnerability contamination by storm runoff, leachates from farms as well as dirty water from the washing of domestic wear. The wooden planks and iron sheets that were used to cover the wells do not protect the wells from storm runoff and dust particles blown by the wind. This is supported by a study done by Munyebvu [20] who attributed contamination of shallow well waters to lack of good aprons and proper headcover.

\section{Conclusions and Recommendations}

The findings of this study present the water quality attributes of the Kamiti-Marengeta sub-catchment from six different regions (Kahawa Wendani, Kenyatta University, Kahawa Sukari, Membley, Bypass, and Kiwanja. The turbidity, calcium, potassium, iron, and fluoride levels in some of the sampled boreholes and concentration of $\mathrm{pH}$, Calcium, Sodium, and Iron in some sampled shallow wells exceeded the KEBS and WHO upper permissible limits for drinking water 
quality. This shows that groundwater in some parts of the study area is chemically unfit for drinking purposes. Turbidity, dissolved oxygen, and total hardness levels significantly varied across the regions of the study. This indicates that as the aquifer unit progressively gets confined and thins towards the end, the drilling depths differ from one region to another, and so is the groundwater exposure to pollution. Contrary to the belief that confined aquifers have impermeable strata above and below hence are not recharged by percolating rainwater, the study findings also highlight seasonal variation in the levels of electrical conductivity, turbidity, total hardness, calcium, and iron in boreholes from the confined aquifer and all tested parameters in shallow wells except Magnesium.

The study recommends that: Water Resources Authority prioritizes interseasonal monitoring of the groundwater quality and improves the groundwater monitoring network within this catchment by either coming into an agreement with owners of production boreholes as well as having the authority's monitoring wells to enable the collection of water quality monitoring data; initiate a comprehensive hydrogeological study to determine the effects of the intensive infrastructure development that have occurred over the last decade on the aquifer rocks; and that the borehole owners invest in water treatment systems to safeguard the health of the residents.

\section{Acknowledgements}

The authors acknowledge the technical support provided by Mr. Kimani, and Madam Christine, laboratory technicians at civil engineering and chemistry laboratories respectively. We are also grateful for the support by departments of Geography and Civil Engineering for the provision of water quality sampling equipment, water quality testing instruments, chemicals, and reagents. This research was partially funded by the Vice Chancellor's Research Grant of 2015/2016 of Kenyatta University.

\section{Conflicts of Interest}

The authors declare no conflicts of interest regarding the publication of this paper.

\section{References}

[1] Dodds, W.K., Perkin, J.S. and Gerken, J.E. (2013) Human Impact on Freshwater Ecosystem Services: A Global Perspective. Environmental Science \& Technology, 47, 9061-9068. https://doi.org/10.1021/es4021052

[2] Knox, P.L., Marston, S.A. and Imort, M. (2016) Human Geography: Places and Regions in Global Context. Pearson, New York, 74 p.

[3] Water Resources Management Authority (WRMA) (2007) Water Resources Allocation Thresholds for Classification of Permits. First Edition, WRMA, Nairobi.

[4] Kiambu County (2013) Kenya Population Statistics and Location in Kenya. http://www.knbs.or.ke/

[5] Kenya National Bureau of Statistics (2019) Kenya Population and Housing Census 
Volume I: Population by County and Sub-County. KNBS, Nairobi. https://www.knbs.or.ke/2019-kenya-population-and-housing-census-reports/

[6] Draphor, S., Obando, J.A., Obiero, K. and Gabiri, G. (2014) Demographic Characteristics of Households and House Ownership Status Influence on Water Demand in Ruiru Municipality, Kiambu County, Kenya. Middle East Journal of Scientific Research, 19, 858-868.

[7] Water Resources Authority (2019) Strategic Plan 2018-2022. WRA, Nairobi, Kenya.

[8] Mumma, A., Lane, M., Kairu, E., Tuinhof, A., Hirji, R. World Bank and Water Partnership Program (2011) Kenya Groundwater Governance: Case Study. World Bank, Washington, DC.

[9] American Public Health Association, Eaton, A.D., American Water Works Association and Water Environment Federation (2005) Standard Methods for the Examination of Water and Wastewater. APHA-AWWA-WEF, Washington, DC.

[10] Aqualytic (n.d.) AL15 MultiMeter Instrument Instruction Manual. Aqualytic, Germany. https://www.manualslib.com/products/Aqualytic-Al15-10490346.html

[11] Manly, B.F. and Alberto, J.A.N. (2016) Multivariate Statistical Methods: A Primer. 4th Edition, Chapman and Hall/CRC, New York. https://doi.org/10.1201/9781315382135

[12] Cohen, J. (2013) Statistical Power Analysis for the Behavioral Sciences. 2nd Edition, Routledge, New York. https://doi.org/10.4324/9780203771587

[13] Yankey, R.K., Akiti, T.T., Osae, S., Fianko, J.R., Duncan, A.E., Amartey, E.O. and Agyemang, O. (2011) The Hydrochemical Characteristics of Groundwater in the Tarkwa Mining Area, Ghana. Research Journal of Environmental and Earth Sciences, 3, 600-607.

[14] World Health Organization (2017) Water Quality and Health Review of Turbidity: Information for Regulators and Water Suppliers (No. WHO/FWC/WSH/17.01). World Health Organization.

[15] Idoko, M. and Oklo, A. (2012) Seasonal Variation in Physicochemical Characteristics of Rural Groundwater of Benue State, Nigeria. Journal of Asian Scientific Research, 2, 574-586.

[16] Sayyed, J.A. and Bhosle, A.B. (2011) Analysis of Chloride, Sodium and Potassium in Groundwater Samples of Nanded City in Mahabharata, India. European Journal of Experimental Biology, 1, 74-82.

[17] Bexfield, L.M. and Jurgens, B.C. (2014) Effects of Seasonal Operation on the Quality of Water Produced by Public Supply Wells. Groundwater, 52, 10-24. https://doi.org/10.1111/gwat.12174

[18] Water Resources Management Authority (WRMA) (2010) Preliminary Water Allocation Plan of the Nairobi Aquifer Suite, and Long-Term Water Resources Management Strategy. Norken (I) Ltd., Nairobi, Kenya.

[19] Hiscock, K.M. (2009) Hydrogeology: Principles and Practice. John Wiley \& Sons, United Kingdom.

[20] Munyebvu, F. (2014) Variations in Groundwater Quality in Protected and Unprotected Water Sources of Murehwa District. Doctoral Dissertation, University of Zimbabwe, Harare. http://www.library.uz.ac.zw/handle/10646/1310 